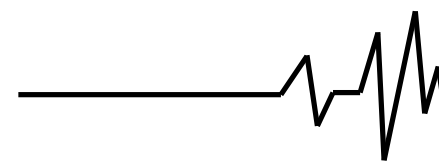

Veselovska N.

Dr. Sc. of Eng., Professor

Malakov 0.

graduate student

Manzhos E.

PhD

Hnatyuk 0.

graduate student

Vinnytsia National Agrarian University

\section{TEST PLANNING OF SERVICEABILITY OF FLEXIBLE PRODUCTION SYSTEMS EQUIPMENT CONSIDERING PLANNING AND MONITORING OF AGRICULTURAL EQUIPMENT}

The article discusses the main problems and features of test planning of serviceability of flexible production systems (FPS) equipment, taking into account all possible factors. The basic dependencies of repair and verification at variable operating modes have been monitored and possiblie ranges of system existence depending on internal factors and changes in working time, environmental characteristics and factors affected the system have been derived. As the result of the analysis, mathematical modeling and determination of critical conditions of existence of the system have been carried out. The basic criteria and tolerances for the normal operation of FPS equipment have been determined. The calculated dependencies for the further improvement of the system and the parameters for the smooth operation of the equipment by means of a mathematical analysis have been found. Methods of test planning of operability of FPS equipment have been developed, the time frame of stopping various systems for the slightest loss of production capacity, taking into account the duration of the diagnostic work of used equipment has been determined.

The planning of inspections for a product that is in a state of readiness for action, possible only after replacement, is considered. These circumstances allow us to determine the optimal interval between inspections by the criterion of minimum expected costs, attributed to the average time of serviceability for the cycle in steady state. When planning inspections of a product that is in a state of static readiness for action, the possibility of making erroneous decisions during the inspection is taken into account. The products which start to act at occurrence of some emergency conditions which moments of occurrence are casual and have distribution $W(t)$ are considered. It is determined that inspections and necessary repairs allow to increase readiness, if at the same time certain conditions concerning quantitative ratios of the sizes influencing it are fulfilled.

Keywords: hardware failures, recurrence ratio, operating losses, overcurrent, operational readiness.
Formulation of the problem. The rapid development of computer science and microprocessor technology has raised to a fundamentally new level the solution of many problems of managing technological and production processes. The transition to automated production has affected many areas of the economy, including engineering. The automation of processes is based on the partial or complete removal of a person from direct participation in the production process. In modern conditions, only such production can be progressive that is able to take into account changes in customer demand and can quickly switch to new products. 


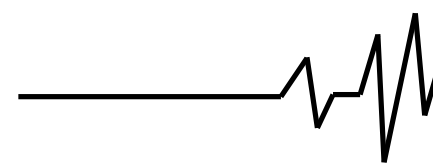

In our country, automatic production lines are widely used, combining complexes of aggregate machines and automatic machines that work automatically. The disadvantage is the narrow focus on the manufacture of a certain type of product. In this regard, such tools can be only used where production is massive and sustainable. In industrialized countries, largescale and mass production is only $20 \%$, and single, small-scale and mass production is $80 \%$ $[1,2,3]$.

In order to resolve the contradictions caused, on the one hand, by the small-scale production facilities, and on the other, by the large scale of production itself, methods of group technology were developed. The next step in the automation of production is the development of programmable and, therefore, reconfigurable tools, that is, flexible equipment, to which they belong CNC machines, machining centers, industrial robots and other equipment.

Formulation of the purpose of research. To consider the main problems and features of planning of inspections of serviceability of the equipment of FPS taking into account all possible factors. Monitor the main dependencies of repair and inspection under variable operating modes, determine the possible ranges of the system depending on internal factors, changes in working hours, environmental characteristics and factors affecting the system. Mathematical modeling and determination of critical conditions of the system existence are carried out. Determine the main criteria and maximum permissible deviations for normal operation of FPS equipment. From the conducted mathematical analysis to find the calculated dependences for further improvement of the system and parameters for the smooth operation of the equipment.

Presentation of the main material research. As a rule, test planning involves the fact that the product being checked, or some part of it, must be removed from the ready state for some time. This means that more frequent tests reduce the useful time during which the system is ready

for action and expects only the occurrence of an accident or alarm, and, on the other hand, less frequent tests reduce the confidence in servicing equipment and, consequently, its ability to perform the resulting problems $[4,5]$. In addition, test planning can significantly increase the failure rate of system equipment or lead to additional malfunctions, while in passive standby or storage, in many cases, the risk of failure is less.

Test planning based on the balance of costs and losses due to malfunction detection.

Let the product in the ready state undergo tests which are carried out in a negligible time without creating the prerequisites for the appearance of additional malfunctions.

Hardware failures will be called malfunctions, emphasizing the fact that they are timely eliminated, they may not lead to a failure to perform some task [6, 7]. We believe that each testing has a fixed cost of $C_{1}$, and the stay of the product in a malfunctioning state for one hour is costed in $C_{2}$. Then a malfunction that occurs at any moment between some kth and $(k+1)$-th tests causes operational losses equal to:

$$
\int_{t_{k}}^{t_{k+1}}\left\{(k+1) C_{1}+C_{2}\left(t_{k+1}-x\right)\right\} d F(x) .
$$
first fault

where $F(x)$ is the distribution of time to the

However, since a malfunction can occur after any test, to calculate the total expected operational loss, it is necessary to add (1) over all possible $\mathrm{k}$ from 0 to $\infty$ :

$$
\int_{t_{k}}^{t_{k+1}}\left\{(k+1) C_{1}+C_{2}\left(t_{k+1}-x\right)\right\} d F(x) .
$$

If the distribution $F(x)$ is continuous and has a moment, then there exists a sequence of non-negative $\left\{\mathrm{F}^{*}{ }_{\mathrm{k}}\right\}$ (which represent the moments of tests) that minimizes the total expected losses of the form (2). This sequence can be found for all $\mathrm{k}$ :

$$
\frac{\partial}{\partial t_{k}}\left\{\int_{t_{k-1}}^{t_{k}}\left[k C_{1}+C_{2}\left(t_{k}-x\right)\right] d F(x)+\int_{t_{k}}^{t_{k+1}}\left[(k+1) C_{1}+C_{2}\left(t_{k+1}-x\right)\right] d F(x)+\right\}=0
$$

or finally

$$
t_{k+1}-t_{k}=\frac{F\left(t_{k}\right)-F\left(t_{k-1}\right)}{f\left(t_{k}\right)}-\frac{c_{1}}{c_{2}}
$$

Where

$$
\mathrm{f}\left(t_{k}\right)=\left.\frac{d F(t)}{d t}\right|_{t=t_{k}} .
$$

Using recurrence relation (4), the optimal values of the test moments $\left\{t^{*}{ }_{k}\right\}$ are successively determined, but for this it is necessary to set the value $t_{1}$, on the basis of which all the other test moments are found [8].

Let the distribution $F_{(t)}$ have an increasing function $\lambda_{(t)}$. Choosing as a moment of the first test some positive number $t_{1}$ and determining with it the subsequent moments of tests by the recurrence formula (4), we establish that if the value $t_{1}$ is chosen so that $t_{1}<t^{*}{ }_{1}$, then for some positive integer values $n$ the relation 


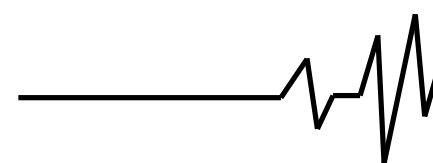

$\Delta_{n}=t_{n+1}-t_{n}>\Delta_{n-1}=t_{n}-t_{n-1}$ holds, and when $t_{1}<t^{*}{ }_{1}$, then for some positive values $n \Delta_{n}<0$.

This justifies an iterative procedure for finding the optimal sequence of tests for a wide class of distributions $F(t)$. For the first approximation, it is recommended to choose a value $t_{1}$ as the moment of the first test, which provides a balance of the cost of one test and the cost of losses from an undetected malfunction that occurs before the first test:

$$
C_{1}=C_{2} \int_{0}^{t_{1}}\left(t_{1}-x\right) d F(x)=C_{2} \int_{0}^{t_{1}} F(x) d x .
$$

Tests can be optimized in the class of periodic checks with a constant period $\tau$. Then the expression for the total expected operational losses will take the form:

$$
C_{1}=C_{2} \int_{0}^{t_{1}}\left(t_{1}-x\right) d F(x)=C_{2} \int_{0}^{t_{1}} F(x) d x .
$$

Such verification strategies are called periodic to distinguish them from variable-interval verification strategies called sequential.

If the form of the distribution law $F(t)$ is unknown, then the task of test planning is formulated somewhat differently. On a finite time interval of duration $T$, it is necessary to plan the number of checks and the intervals between them so that a minimum of the maximum possible losses of the form (6) is achieved for any distribution $F(t)$. Since $T$ is of finite value, the class of strategies sought is constituted by sequentially periodic strategies with period $T$ [9, 10]. In this case, it is not difficult to imagine the operational losses due to a malfunction arising between the $k$-th and $(k+1)$-th checks $(k=0,1,2, \ldots, n-1)$.

If $\xi$ is the random moment of occurrence of the malfunction, then under various conditions of its occurrence in time, the losses will be equal to:

$$
\omega(\xi)= \begin{cases}(k+1) C_{1}+C_{2}\left(t_{k+1}-\xi\right), \text { если } t_{k}<\xi \leq t_{k+1}, k=0,1_{s .}, n-1, \\ n C_{1}+C_{2}(T-\xi), & \text { если } t_{n}<\xi \leq T, \\ C_{1} n, & \text { если } \xi>T .\end{cases}
$$

Since a malfunction can occur at any time in a given interval or may not occur at all during the time $[0, T]$, the total expected losses M [C_э $(T)$ ] during this time will be equal to:

$$
\omega(\xi)= \begin{cases}(k+1) C_{1}+C_{2}\left(t_{k+1}-\xi\right), \text { если } t_{k}<\xi \leq t_{k+1}, k=0,1_{s, n} n-1, \\ n C_{1}+C_{2}(T-\xi), & \text { если } t_{n}<\xi \leq T, \\ C_{1} n, & \text { если } \xi>T .\end{cases}
$$

For expression (8), it is essential that the last test is carried out up to time $T$.

With an unknown distribution of the moment of occurrence of the malfunction $F(t)$, planning can be formulated on the basis of the minimax criterion:

$$
\begin{aligned}
& \min _{\left.\mathbb{T}_{k}\right]_{n}} \max _{F(\mathbb{R})} M\left[C_{3}\left(t_{1, \ldots,}, t_{n}\right) F(t)\right]_{,} k=0, \ldots, n_{s} \\
& \sum_{k=0}^{n-1} \int_{t_{k}}^{T_{k+1}}\left\{(k+1) C_{1}+C_{2}\left(t_{k+1}-x\right)\right\} d F(x)+\int_{t_{n}}^{T}\left\{n C_{1}+C_{2}(T-x)\right\} d F(x)+n C_{1} \int_{T}^{m e} d F(x) \leq \\
& \sum_{k=0}^{n-1}\left[(k+1) C_{1}+C_{2}\left(t_{k+1}-t_{k}\right)\right]\left[F\left(t_{k+1}\right)-F\left(t_{k}\right)\right]+\left[n C_{1}+C_{2}\left(T-t_{n}\right)\right]\left[F(T)-F\left(t_{n}\right)\right] \\
& +n C_{1}[1-F(T)] \leq \max _{\mathbb{Z}}\left(\omega_{0, x^{3}, \ldots,}, \omega_{k, x^{y}} \ldots, \omega_{n, x}\right) \text {. }
\end{aligned}
$$

where

$$
\begin{gathered}
\omega_{n x x}=n C_{1}+C_{2}\left(T-t_{n}\right) ; \\
\omega_{k, x}=(k+1) C_{1}+C_{2}\left(t_{k+1}-t_{k}\right), k=0,1_{s, n} n-1_{x}
\end{gathered}
$$




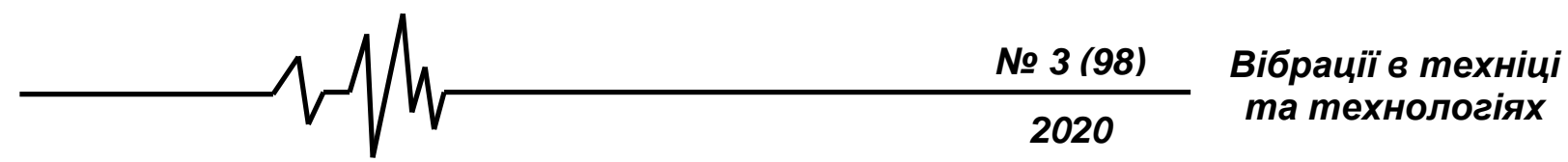

- losses due to a malfunction immediately after the next $k$-th test according to schedule $x$ out of $n$ checks. It is clear that $\max _{k}\left(\omega_{0, x}, \ldots, \omega_{k, x}, \ldots, \omega_{n, x}\right)=\omega^{*}{ }_{x}$

represents the maximum possible loss.

The minimum verification strategy comes down to choosing the number of tests $n$ as the largest integer satisfying the inequality:

$$
C_{1} n^{2}+C_{1} n+2\left(C_{1}-C_{2} T\right) \leq 0,
$$

and the moments of successive tests themselves are determined according to the expression:

$$
t_{k}=k\left[\frac{T}{n+1}+\frac{c_{1}}{2 c_{2}}\left(\frac{n(n+3)}{(n+1)}-(k+1)\right)\right]
$$

To prove this, we choose a positive integer $N$ such that $N(N-1) \leq 2 T C_{2} / C_{1}, n(n-1)>2 T C_{2} / C_{1}, n>N$. We denote by $I_{n}$ the class of all schedules (sequences) of tests on the interval $[0, T]$, consisting of $n$ tests, and by $I_{N}$, the union of all classes of schedules of tests containing from 0 to $N$ tests $(0,1,2, \ldots, M)$. Let $x(n)$ be a graph of $n$ tests belonging to the class $I_{n}$ (which can be more briefly written as $x(n) \in I_{n}$, such that the losses due to a malfunction immediately after any test are equal to:

$$
\omega_{0, x(n)}=\omega_{1, x(n)}=\cdots=\omega_{n, x(n)}=\omega_{x(n), n \leq N .}
$$

Let also $I^{*}$ be the class of such verification graphs $x(0) \ldots, x(N)$.

To prove the validity of (11) and (12), it is necessary to show that: 1) if the graph $x \in I_{n}$ under the condition $n>N$, then the losses due to the adoption of this graph satisfy the inequality $\omega^{*}{ }_{x}>\omega_{x(N)}$ ( thus, if a graph $x^{*}$ satisfying the minimax strategy exists, then it belongs to the class $\left.I_{N}\right) ; 2$ ) the graph $x^{*}$ exists and belongs to the class $I^{*}$ and 3) equation (11) allows us to find this graph $x^{*}$ in the class $I^{*}$.

1 . For any graph $x \in I_{n}$, you can write:

$$
\begin{gathered}
\left\{\begin{array}{c}
(k+1) C_{1}+C_{2} \Delta_{k}, \Delta_{k}=t_{k+1}-t_{k}, k=0,1_{s}, n-1_{x} \\
C_{1} n+C_{2} \Delta_{n}, \Delta_{n}=T-t_{n}, k=n_{v}
\end{array}\right. \\
\omega_{k-1 x}=k C_{1}+C_{2} \Delta_{k-1}, k=1_{s, n} n_{x} .
\end{gathered}
$$

Using (14), from the condition of equality of losses when applying the graph $x(n)$, we can obtain the expression for $t_{k}$ :

$$
\omega^{*}{ }_{x(n)}=\frac{C_{2} \mathrm{~T}+\frac{\mathrm{nC} C_{1}}{2}(n+\mathrm{a})}{n+1}, n=0, \ldots, N,
$$

since $\Delta_{k}>0(k=0,1, \ldots, n)$. The graph $x(n)$ is not defined for $n>N$, since $\Delta_{n} \leq 0$. Now suppose that $\omega^{*}{ }_{x} \geq C_{1} n$, since $C_{1} n$ is the loss due to tests in the absence of malfunctions or if a malfunction occurs immediately before the $n$-th test. Therefore, taking into account the choice of $N$, we can write:

$$
\begin{gathered}
\omega_{x}^{*}-\omega^{*}{ }_{x(n)} \geq C_{1} n-\frac{C_{2} T+\frac{N C_{1}}{2}(N+\mathrm{B})}{N+1} \geq \\
\geq C_{1}(N+1)-\frac{C_{2} T+\frac{N C_{1}}{2}(N+1)}{N+1}= \\
=\frac{\frac{C_{1}}{2} N(N+1)-C_{2} T+C_{1}}{N+1}> \\
>\frac{\frac{C_{1} 2 T C_{2}}{2 C_{1}}-C_{2} T+C_{1}}{N+1}=\frac{C}{N+1}>0 .
\end{gathered}
$$

2. Fix $n<N$. If $n=0$, then $x(0)$ is the only possible graph in the complete absence of tests. Let for $n>0 \bar{x}$ be such a schedule of $n$ tests, using which the maximum possible loss is less than the losses caused by the schedule $x(n)$.

\section{$\sum_{k=0}^{n} \omega_{k x}<\sum_{k=0}^{n} \omega_{k x(n)}$.}

Summing up expressions (14), for all graphs $x \in I_{n}$ we have:

$$
\sum_{k=0}^{n} \omega_{k x}=\frac{n C_{1}(n+a)}{2}+C_{2} T=\sum_{k=0}^{n} \omega_{k y x}(n) x
$$

From this we conclude that the last equality contradicts the condition:

$$
\sum_{k=0}^{n} \omega_{k x}<\sum_{k=0}^{n} \omega_{k x}(n) .
$$

Therefore, the graph $\bar{x}$ does not exist, and therefore, $x^{*} \in I^{*}$. But since the class $I^{*}$ contains a finite number of graphs, the graph $x^{*}$ exists.

3. Therefore:

$$
\begin{aligned}
& \omega_{x(n)}^{*}-\omega^{*}{ }_{x(n-1)}=\left(C_{1} n^{2}+C_{1} n+2\left(C_{1}-C_{2} T\right)\right) / \\
& (2 n(n+1))
\end{aligned}
$$

moreover, the sign of this difference corresponds to the sign of the numerator of the fraction. Therefore, $\omega^{*}{ }_{x(n)}$ does not increase as long as the fraction numerator is less than zero $[11,12]$. However, the numerator is an increasing 


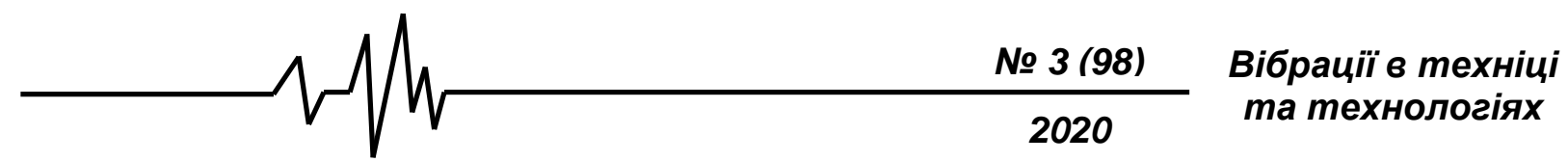

function of $n$ and greater than zero for $\mathrm{n}=\mathrm{N}$. This means that the number of tests in the graph $x^{*}=x(n)$ is determined from equation (11).

The test planning for a given time interval $[0, T]$ is generalized to the case when the test itself may turn out to be unreliable and lead to the detection of a malfunction with a finite probability $p>0$. Then the expression (12) takes the form:

$$
t_{k}=k p\left[\frac{T}{n p+1}+\frac{n C_{1}}{2 C_{2}}\left(\frac{n(p(n+1)+2)}{n p+1}-(k+1)\right)\right], k=0,1_{n, \ldots, n} n
$$

and the number of tests $\mathrm{n}$ can be found from the equation:

$$
C_{1} p^{2} n^{2}+C_{1} p(2-p) n+2\left(C_{1}-p C_{2} T\right)=0 .
$$

Test planning carried out after replacement of the equipment.

Now we consider the test planning for a product in a state of readiness for action, possible only after replacement. We believe that the product consists of one replaceable unit, the failure time of which has an arbitrary distribution $F(t)[13,14]$.

Since the replacement leads to a complete update of the product, for the steady state at $t \rightarrow \infty$ we can restrict ourselves to considering one interval between replacements. This means the choice of a verification strategy in the class of periodic strategies. Denote by $\tau$ the interval between two consecutive substitutions (tests), and by $\tau_{\tilde{a}}$ the average replacement time. Let the cost of one replacement is equal to $C_{a}$, and the depreciation rate is $A$ rublh. It is necessary to choose an interval between replacements $\tau^{*}$ so that the expected operating costs per cycle $\left(\tau+\tau_{a}\right)$, referred to the average time of the state of serviceability during this cycle, reach a minimum, i.e. the ratio was minimized:

$$
\min _{\tau} \frac{C_{3}+A\left[\tau+\tau_{3}\right)}{\int_{0}^{2}(1-F(t)) d t}
$$

where $\int_{0}^{\pi}(1-F(t)) d t$ is the average working time of the product per cycle.

Let $\quad F(t)=1-\exp (-\lambda t), t \geq 0$.

Differentiating the $\tau$ expression minimized in (18) and equating the derivative to zero, we obtain the equation for calculating the optimal interval between tests presented below:

$$
\frac{\exp (\lambda \tau)}{\lambda}=\frac{1}{\lambda}+\tau+\tau_{a}+\frac{C_{3}}{A} x
$$

The optimal value of the time interval between tests is approximately equal to:

$$
\tau^{*} \approx \frac{\sqrt{2\left(\pi_{3}+\frac{C_{2}}{A}\right)}}{\lambda} .
$$

With the exponential distribution of the time of state of serviceability, the test has a restoring property, that is, after checking, provided the product is found to be working, it becomes, so to say, "new". This circumstance allows us, in the same way as in the case of replacements, to determine the optimal interval between inspections by the criterion of the minimum of expected costs attributed to the average time of a state per cycle in the steady state, that is, [15].

$$
\min _{\tau} \frac{A\left[\tau^{s}+T_{\mathrm{n}}+[1-\operatorname{mexp}(-\lambda \tau)] \tau_{3}\right)+C_{\mathrm{n}}+\left[(1-\pi \exp (-\lambda \tau)] C_{3}\right.}{\int_{0}^{\tau}(1-F(t)) d t},
$$

where the expected cycle time is:

$$
M\left[T_{\mathrm{m}}\right]=\tau+T_{\mathrm{m}}+(1-\pi \exp (-\lambda \tau)) \tau_{\mathrm{a}} \text { : }
$$

$C_{\mathrm{m}}, T_{\mathrm{m}}, \pi$ - respectively, the cost of one check, the time required to test, and the likelihood that the product will not fail during the test. The optimal value of the time interval between tests is:

$$
\tau^{*} \approx \sqrt{\frac{2 T_{n}+\frac{C_{\pi}}{A}+(1-\pi)\left(\tau_{3}+\frac{C_{3}}{A}\right)}{\lambda}} .
$$

It should be noted that in the last model of tests, unlike the previous ones, the replacement is carried out only when a malfunction is detected, and the test itself may cause additional malfunctions. In the process of test planning of a product that is in a state of static readiness for action, the possibility of making erroneous decisions during the test is taken into account [16]. 


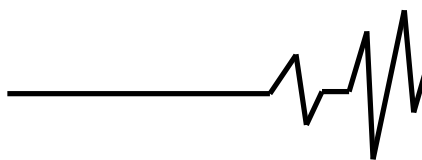

If the reliability of the equipment of the designed system is not well known, i.e., if, for example, it is known that the distribution $F(t)$ is exponential, and the estimate of the parameter $\lambda$ is given by the a priori distribution $g(\lambda)$ with known parameters, then the initial value is $\tau^{*}{ }_{1}$ can be calculated by averaging over all possible values of $\hat{\hat{\lambda}}$ the derivative (21) over $\pi$. Let the intensity of the occurrence of malfunctions have an a priori density of the form of a gamma distribution with parameters $a$ and $t_{1}$ and after making the initial decision $\tau^{*}{ }_{1}$, additional information was obtained on the results of observations of this or similar systems in operation [17]. This information is a set

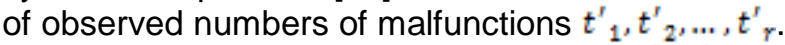
Having calculated the posterior density $g(\lambda \mid r)$, we can proceed to determine the refined value $\tau^{*}{ }_{2}$ from the equation:

$$
\frac{\partial}{\partial \tau}\left(\int_{0}^{\infty \pi} C_{3}(\tau, \lambda) g(\lambda \mid r) d \lambda\right)=0,
$$

where

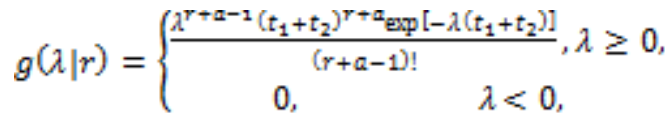

$$
\begin{aligned}
& t_{2}=\sum_{i=1}^{P} t_{\mathrm{i}^{x}}^{s}
\end{aligned}
$$

Here $C_{3}(\tau, \lambda)$ is the total expected cost per cycle. Transferring the differentiation with respect to $\tau$ under the integral sign and integrating the term-by-term expression obtained, we obtain the following equation with respect to the verification interval $\pi$ :

$$
\frac{\left(\tau+t_{1}+t_{2}\right)^{r+a}}{\left(t_{1}+t_{2}\right)^{r+a-1}}-(r+a) \tau-\left(\tau_{a}+\frac{C_{2}}{A}\right)(r+a-1)=t_{1}+t_{2},
$$

which is usually solved by numerical methods. Introducing the notation $\tilde{\lambda}=(r+a) /\left(t_{1}+t_{2}\right), t_{1}+t_{2} \equiv t$, expression (27) can be rewritten in a slightly different form:

$$
\left(1-\frac{\pi}{t}\right)^{\pi t}-\left(\tau+\tau_{a}+\frac{C_{3}}{A}\right) \pi-\frac{\left(\tau_{3}+\frac{C_{3}}{A}\right)}{t}=1
$$

On the basis of (28) it can be shown that when $r$ - the number of observed failures becomes sufficiently large, (27) takes the form of equation (19). Indeed, as $r \rightarrow \infty$, the estimate $\tilde{\lambda}$ tends to the true value $\lambda_{0}, t \rightarrow \infty$, the first term in (28) tends to $\exp \left(\lambda_{0} \tau\right)$, and the third term tends to zero. With this approach, a number of problems arise related to the existence and conditions of convergence of the sequence of solutions $\tau^{*}{ }_{1}, \tau^{*}{ }_{2 \ldots}$ for various a priori distributions $g(\lambda)$. From a practical point of view, the speed of convergence of the sequence of solutions $\tau^{*}{ }_{1}, \tau^{*}{ }_{2 \ldots}$ or, in other words, the necessary amount of additional tests or observations of the reliability of the system or its possible analogue is of interest.

Test planning based on the criterion of the maximum of the operating readiness coefficient.

Let us consider products that begin to act in the event of some, for example, emergency conditions, the moments of occurrence of which are random and have a distribution of $W(t)$. If we denote by $K(t)$ the probability that the product is in good condition at time $t$, then the probability that arising tasks catch it in good condition during the time interval $[0, T]$ is:

$$
P(T)=\int_{0}^{T} K(t) d W(t)
$$

If the distribution $W(t)$ is uniform, that is

$$
(t)=\left\{\begin{array}{l}
0 \quad \text { при } t \leq 0, \\
\frac{t}{T} \text { при } 0 \leq t \leq T_{v} \\
1 \quad \text { при } t>T_{v}
\end{array}\right.
$$

then expression (29) can be rewritten as:

$$
P(T)=\int_{0}^{T} K(t) d W(t)=\frac{1}{T} \int_{0}^{T} K(t) d t .
$$

Recall that the operational readiness coefficient of a product is defined as:

$$
\lim _{T \rightarrow \infty} \frac{1}{T} \int_{0}^{T} K(t) d t
$$

Tests and necessary repairs can improve availability if certain conditions are met regarding the quantitative ratios of the quantities that it affects. Assume that a constant intensity $\lambda$ is observed between the tests, and additional failures may occur during the tests. Let $T_{\mathrm{m}}$ be the average duration of one check, and $T_{\mathrm{p}}$ - the average duration of one repair, after which the product is completely updated. Since $\lambda$ is constant in time, a similar update occurs after verification, as a result of which it is established that the product is working. The test itself may also cause a 


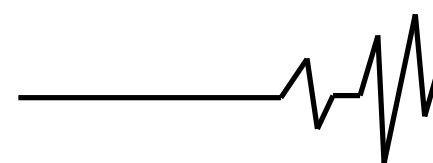

malfunction. We assume that the system can fail during the next test with probability $\pi_{1}>0$, and with a probability of $1-\rho$ this event can be detected only during a subsequent test. Tests related to turning on the equipment usually result in short-term exposure to voltages, overcurrent, and other types of overloads. This justifies the introduction of time-independent probabilities, reflecting the danger of the impact of this regime on products. The probability $\rho$ reflects the possibility of failure immediately before the test [18].

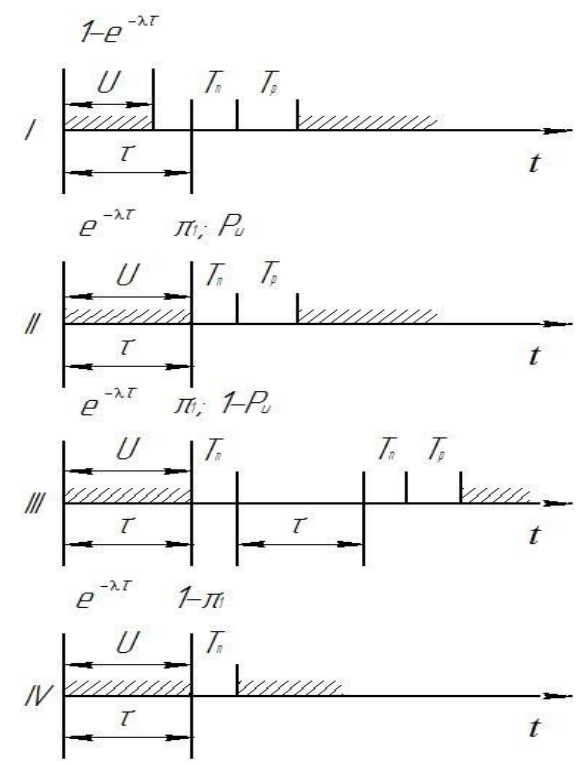

\section{Fig. 1. Timing chart explaining various possible faults}

There are four different possibilities for a malfunction, which are shown schematically in Fig. 1. It can be shown that at $T \rightarrow \infty$, the availability indicator $P(T)$ converges to the mathematical expectation of one interval of the state of

serviceability divided by the sum of the mathematical expectations of the interval of the state of serviceability and the downtime between two successive intervals of the state of serviceability. On this basis, operational readiness can be represented as:

$$
\lim _{T \rightarrow \infty} \frac{1}{t} \int_{0}^{T} K(t) d t=\frac{M(U)}{M[U]+M[v]},
$$

where $M[U]$ и $M[V]$ are the indicated mathematical expectation of the intervals of the state of serviceability and downtime.

To describe the procedure of test planning, a malfunction may occur with a probability of $1-\exp (-\lambda \tau)$ for the interval $[0, \tau]$ or may not occur with a probability of $\exp (-\lambda \tau)$. Thus, the operational readiness on the basis of (33) can be written in the form:

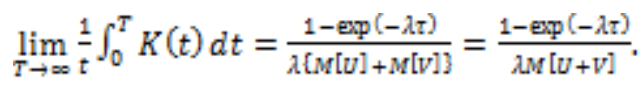

It remains to calculate $M[U+V]$. For the first sequence of intervals in Fig. 1 the expected cycle time between two periods of good condition is:

$$
M[U+V]_{1}=\tau+T_{\text {п }}+T_{\mathrm{p}},
$$

and for the second, third and fourth sequences it is represented as:

$$
M[U+V]_{2, a / 4}=\left(\tau+T_{\mathrm{m}}\right)\left[\pi_{1}(1-\rho)+1\right]+T_{\mathrm{p}} \pi_{1} .
$$

Using expressions (35) and (36), we find $M[U+V]$ :

$$
\begin{array}{r}
M[U+V]=(1-\exp (-\lambda \tau)) M[U+V]_{1}+\exp (-\lambda \tau) M[U+V]_{2}= \\
=\left(\tau+T_{\mathrm{m}}\right)\left\{1+\pi_{1}(1-\rho) \exp (-\lambda \tau)\right\}+T_{\mathrm{p}}\left[1-\left(1-\pi_{1}\right) \exp (-\lambda \tau)\right] .
\end{array}
$$

Expression (37) allows us to represent the operational readiness of a periodically inspected product as follows:

$$
\lim _{T \rightarrow 0} \frac{1}{T} \int_{0}^{T} K(t) d t=\frac{1-\exp (-\lambda \tau)}{\lambda\left(\tau+T_{n}\right]\left[1+\pi_{1}(1-\rho) \exp (-\lambda \tau)\right]+\lambda T_{0}\left[1-\left(1-\pi_{1}\right] \exp (-\lambda \tau)\right]^{2}}
$$

To determine the optimal period of test planning, (38) it is necessary to differentiate to $\tau$, equate the derivative to zero and solve the resulting equation to $\tau$. In some cases, the tests may be unexpected, that is, as a result of the test, the serviceable product can be mistaken for a faulty one and, conversely, it will not be possible to detect a malfunction [19].

One of the types of monitoring of the serviceability of a product is based on the condition according to which the probability of a 


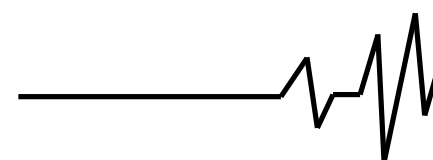

transition from the state of serviceability to malfunctions on the time interval between tests, if the product was functioning before, remains constant at all intervals, i.e.:

$$
\begin{aligned}
& \frac{F\left(t_{k}\right)-F\left(t_{k-1}\right)}{1-F\left(t_{k-1}\right)}=p, k=1,2, \ldots, \text { (39) } \\
& \text { where } t_{0}=0 ; F(0)=0 \text {. You can }
\end{aligned}
$$
also notice that $F\left(t_{1}\right)=p$. We rewrite equation (39) in the form:

$$
F\left(t_{k}\right)=p+\rho F\left(t_{k-1}\right) .
$$

Equation (40) is easy to solve for $t_{k}$. Indeed, $F\left(t_{k}\right)=1-\rho^{k}=1-(1-p)^{k}$, where $\rho=1-p$. Thus, for a given level of probability $\mathrm{p}$, the instant $t_{k}$ is found:

$$
\begin{aligned}
& T_{c}=\sum_{k=1}^{\infty} \int_{t_{k-1}}^{t_{k}}\left(t_{k}-t\right) \oint(t) d t= \\
& \sum_{k=1}^{\infty} t_{k}-\left[F\left(t_{k}\right)-F\left(t_{k-1}\right)\right]- \\
& \int_{0}^{\infty} t \oint(t) d t
\end{aligned}
$$

$$
t_{k}=F^{-1}\left(1-\rho^{k}\right) \text {. }
$$

For such a test planning strategy, the number of tests required to detect a product malfunction is $k$ with probability:

$$
P\{N=1\}=\rho^{k-1} p, k=1,2, \ldots,
$$

and the average number of such tests is:

$$
M[N]=\sum_{k=1}^{\infty} k \rho^{k-1}=\frac{1}{1-\rho}=\frac{1}{\rho} .
$$

If a failure occurs at time $t<t_{k}$, then it can be detected only at time $t_{k}$, and $t_{k}-t$ is the time spent in the state of an undetected failure. Therefore:

$$
\begin{gathered}
T_{c}=\sum_{k=1}^{m} \int_{t_{k-1}}^{T_{k}}\left(t_{k}-t\right) \oint(t) d t=\sum_{k=1}^{m e} t_{k}-\left[F\left(t_{k}\right)-F\left(t_{k-1}\right)\right]-\int_{0}^{\infty e} t \oint(t) d t \\
\text { or } T_{c}=\sum_{k=1}^{\infty} t_{k} \rho^{k-1} p-M[\xi]
\end{gathered}
$$

Given that $T_{c}=T(p)$, we have $M\left[C_{3}\right]=C_{1} / p+C_{2} T(p)$ or else $M\left[C_{3 k}\right]=M\left[k C_{1}+C_{2}\left(t_{k}-t\right)\right]$.

Expected costs, as before, for a control procedure of this type are:

$$
M\left[C_{3}\right]=\sum_{k=0}^{\infty} \int_{t_{k}}^{t_{k+1}}\left\{C_{1}(k+1)+C_{2}\left(t_{k+1}-x\right)\right\} d F(x) .
$$

and therefore, the average costs are found taking into account the relations for $T(p)$ and $M[N]$, that is:

$$
M\left[C_{3}\right]=\frac{c_{1}}{p}+C_{2} T(p) .
$$

Conclusions. The basic dependencies of test planning and repair under variable operating modes have been monitored and the ranges of existence of the system depending on internal factors and changes in working time, environmental characteristics and factors affecting the system have been obtained.

Several methods of mathematical test planning on the operability of the FPS equipment have been analyzed and developed, taking into account the impact of all possible negative factors on the system.

\section{References}

1. Automation of technological processes: Textbook for students. environments. prof. education / Vladimir Shishmarev .- M.: Publishing center "Academy", 2005. (Rus).

2. Production Automation and Mechanization: Textbook. study guide. environmental institutions. prof. education / BI. Cherpakov, L.I. Vereina. - M.: Academy Publishing Center, 2004. (Rus).

3. Automation of technological processes and systems of automatic control: Tutorial / Baralo OV, Samoilenko PG, Granat SE, Kovalev VA - K.: Agrarian education, 2010. - P. 557. (Ukr).

4. Martynenko II Automation of technological processes of agricultural production 


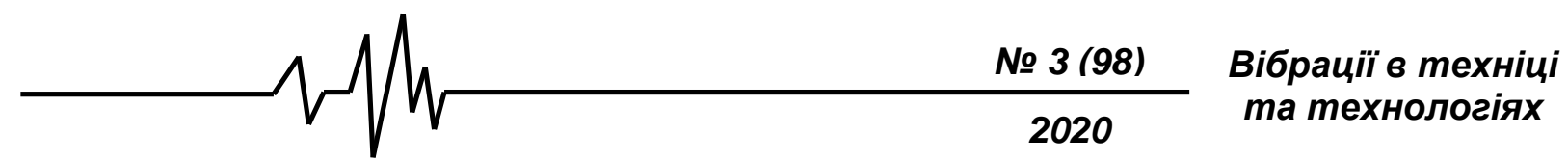

[Electronic resource] / II Martynenko // K.: Harvest. 1995. - Resource Access Mode: https://buklib.net/books/35489/. (Ukr).

5. Automation and mechanization of production [Electronic resource] // My education. 2017. - Resource access mode: http://moyaosvita.com.ua/osvita-2/avtomatizaciyai-mexanizaciya-virobnictva/. (Ukr).

6. Technical Means of Automation: Guidelines for Coursework for Students of Specialties 6.092502 of All Forms of Education / Comp. S.A. Kirichuk; Yu.B. Belyaev. - K.: NUKHT, 2005. (Ukr).

7. Automated shaft machining complexes using industrial robots. Method. recommendations, ENIMS. - M.: Nlimash, 1983, P. 64 p. (Rus).

8. Grachev LN Automated sections for precise dimensional processing of parts. - M.: Mechanical Engineering, 1981, - P. 240. (Rus).

9. Flexible automatic production. / Ed. Mayorova SA and Orlovsky GV - L.: Mechanical Engineering, Leningrad Branch, 1983. - P. 376. (Ukr).

10. Production Automation. Stages of development and prospects [Electronic resource] // Educational materials. - 2003. - Resource Access Mode: https://works.doklad.ru/view/Kisg2XfabM.html.

11. Automation of technological processes [Electronic resource] // Educational materials. - 2005. - Resource access mode: https://works.doklad.ru/view/-VnbSZbfBgA.html.

12. Automation of Production Processes [Electronic resource] // ELARTU. 2011. - Resource access mode: http://elartu.tntu.edu.ua/handle/123456789/1551.

13. Klyuev AS "Design of process automation systems" - M.: Energoatomizdat, 1990. (Rus).

14. Gavrish OP Robotization of machining complexes of machine-building production. - To.: Technics, 1984, 198198

15. Flexible Manufacturing Complexes / Sub. ed. Bp Belyanina and V.A. Leshchenko. - .: Mechanical Engineering, 1984. - P. 384 (Rus).

16. Automation of technological processes [Electronic resource] // FreePapers. 2013. - Resource access mode: http://freepapers.ru/33/avtomatizacya-

tehnologchnih-procesv/258758.1715325.list1.html.

17. AP Ladaniuk, VG Tregub, IV Elperin, VD Tjutsyura. "Automation of technological processes and production of food industry". K.: Agricultural Education, 2001. (Ukr).

18. Dashchenko A.I. Design of automatic lines. - M.: Higher School, 1983. - P. 328. (Rus).

19. Poletayev VA, Tretyakova NV, Development of layout and planning of flexible production systems. Methodical instructions. Ivanovo, IGEU, 1999. (Rus).

\section{ПЛАНИРОВАНИЕ ПРОВЕРОК ИСПРАВНОСТИ ОБОРУДОВАНИЯ ГИБКИХ ПРОИЗВОДСТВЕННЫХ СИСТЕМ С УЧЕТОМ ПЛАНИРОВАНИЯ И МОНИТОРИНГА СЕЛЬСКОХОЗЯЙСТВЕННОГО ОБОРУДОВАНИЯ}

В статье рассматриваются основные проблемы и особенности планирования проверок исправности оборудования ГПС (гибких производственных систем) с учетом всех возможных факторов. Проведен мониторинг основных зависимостей ремонта и проверки при переменных режимах эксплуатации и выведены возможные диапазоны существования системы в зависимости от внутренних факторов и изменения показателей рабочего времени, характеристик окружающей среды и фракторов воздействия на систему. В результате анализа проведено математическое моделирование и определение критических условий существования системы. Определены основные критерии и предельно допустимые отклонения для нормальной работы оборудования ГПС. Из проведенного математического анализа найдены расчетные зависимости для дальнейшего совершенствования системы и параметры для бесперебойной работы оборудования. Разработанные методики планирования проверок работоспособности оборудования ГПС, определенные временные рамки для остановки тех или иных систем для малейшей потери производственных мощностей с учетом продолжительность проведения диагностических работ используемого оборудования.

Рассмотрены планирование проверок для изделия, находящегося В состоянии готовности к действию, возможных только после замены. Указанные обстоятельства позволяют определить оптимальный интервал между проверками по критерию минимума ожидаемых расходов, отнесенных к среднему времени исправного состояния за цикл в установившемся режиме. При планировании проверок изделия, находится В состоянии статического готовности к действию, учитываются возможности принятия ошибочных решений при проведении проверки. Рассмотрены изделия, которые начинают действовать при возникновении некоторых аварийных условий, моменты наступления которых случайные и имеют распределение W (t). Определено, что проверки и необходимые 
$\longrightarrow 1$

ремонты позволяют повысить готовность, если при этом выполнены некоторые условия, касающиеся количественных соотношений величин, влияющих на нее.

коэффрициент

Ключевые слова: аппаратные сбои, эксплуатационные потери, чрезмерный ток, эксплуатационная готовность.

\section{ПЛАНУВАННЯ ПЕРЕВІРОК СПРАВНОСТІ ОБЛАДНАННЯ ГНУЧКИХ ВИРОБНИЧИХ СИСТЕМ 3 УРАХУВАННЯМ ПЛАНУВАННЯ ТА МОНІТОРИНГУ СІЛЬСЬКОГОСПОДАРСЬКОГО ОБЛАДНАННЯ}

У статті розглядаються основні проблеми та особливості планування перевірок справності устаткування ГВС (гнучких виробничих систем) 3 урахуванням всіх можливих фракторів. Проведено моніторинг основних залежностей ремонту і перевірки при змінних режимах експлуатації та виведені можливі діапазони існування системи в залежності від внутрішніх чинників і зміни показників робочого часу, характеристик навколишнього середовища та фракторів впливу на систему. В результаті аналізу проведено математичне моделювання та визначення критичних умов існування системи. Визначено основні критерії та гранично допустимі відхилення для нормальної роботи устаткування ГВС. 3 проведеного математичного аналізу знайдені розрахункові залежності для подальшого вдосконалення системи та параметри для безперебійної роботи обладнання. Розроблені методики планування перевірок працездатності устаткування ГВС, певні часові рамки для зупинки тих чи інших систем для найменшої втрати виробничих потужностей 3 огляду на тривалість проведення діагностичних робіт використовуваного обладнання.

Розглянуто планування перевірок для виробу, що знаходиться в стані готовності до дії, можливих тільки після заміни. Зазначені обставини дозволяють визначити оптимальний інтервал між перевірками за критерієм мінімуму очікуваних витрат, віднесених до середнього часу справного стану за цикл в сталому режимі. При плануванні перевірок вироби, що знаходиться в стані статичної готовності до дії, враховуються можливості прийняття помилкових рішень при проведенні перевірки. Розглянуто вироби, які починають діяти при виникненні деяких аварійних умов, моменти настання яких випадкові і мають розподіл W (t). Визначено, що перевірки і необхідні ремонти дозволяють підвищити готовність, якщо при цьому виконані деякі умови, що стосуються кількісних співвідношень величин, що впливають на неї.

Ключові слова: апаратні збої, коефіцієнт повторності, експлуатаційні втрати, надмірний струм, експлуатаційна готовність.

\section{Відомості про автора}

Веселовська Наталія Ростиславівна - доктор технічних наук, професор, завідувач кафедри машин та обладнання сільськогосподарського виробництва Вінницького національного аграрного університету (вул. Сонячна, 3, м. Вінниця, Україна, 21008, e-mail: wnatalia@ukr.net).

Веселовская Наталья Ростиславовна - доктор технических наук, профессор, заведующий кафедрой машин и оборудования сельскохозяйственного производства Винницкого национального аграрного университета (ул. Солнечная, 3, г.. Винница, Украина, 21008, e-mail: wnatalia@ukr.net).

Veselovskaya Natalia Rostislavivna - Doctor of Technical Sciences, Professor, Head of the Department of Machinery and Equipment of Agricultural Production of Vinnytsia National Agrarian University (3 Sonyachna Street, Vinnytsia, Ukraine, 21008, e-mail: wnatalia@ukr.net).

Малаков Олександр Іванович - аспірант кафедри машин та обладнання сільськогосподарського виробництва Вінницького національного аграрного університету (вул. Сонячна, 3, м. Вінниця, Україна, 21008 e-mail: malakovsana@gmail.com).

Малаков Александр Иванович - аспирант кафедры машин и оборудования сельскохозяйственного производства Винницкого национального аграрного университета (ул. Солнечная, 3, г. Винница, Украина, 21008 e-mail: malakovsana@gmail.com). 


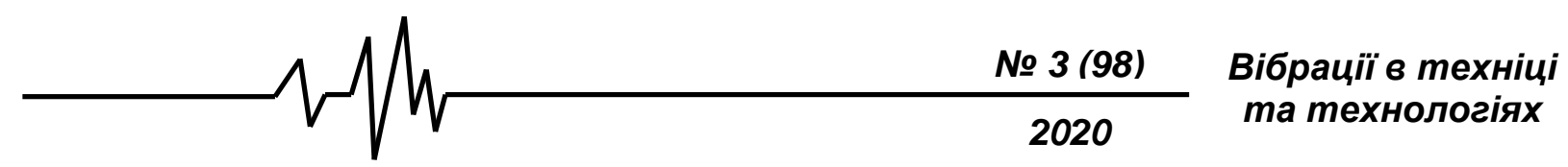

Malakov Oleksandr Ivanovych - graduate student of the Department of Machinery and Equipment of Agricultural Production of Vinnytsia National Agrarian University (3 Sonyachna Street, Vinnytsia, Ukraine, 21008 e-mail: malakovsana@gmail.com).

Манжос Ельвіра Олександрівна - старший викладач кафедри українських та іноземних мов Вінницького національного аграрного університету (вул. Сонячна, 3, м. Вінниця, Україна, 21008 e-mail: pv.vnau@ua.fm).

Манжос Эльвира Александровна - старший преподаватель кафедры украинских и иностранных языков Винницкого национального аграрного университета (ул. Солнечная, 3, г.. Винница, Украина, 21008 e-mail: pv.vnau@ua.fm).

Manzhos Elvira Oleksandrivna - Senior Lecturer, Department of Ukrainian and Foreign Languages, Vinnytsia National Agrarian University (3 Sonyachna Street, Vinnytsia, Ukraine, 21008 email:pv.vnau@ua.fm).

Гнатюк Олена Федорівна - аспірант кафедри машин та обладнання сільськогосподарського виробництва Вінницького національного аграрного університету (вул. Сонячна, 3, м. Вінниця, Україна, 21008 e-mail: alenagnatyuk1@gmail.com).

Гнатюк Елена Федоровна - аспирант кафедры машин и оборудования сельскохозяйственного производства Винницкого национального аграрного университета (ул. Солнечная, 3, г.. Винница, Украина, 21008 e-mail: alenagnatyuk1@gmail.com).

Hnatyuk Olena Fedorivna - graduate student of the Department of Machinery and Equipment of Agricultural Production of Vinnytsia National Agrarian University (3 Sonyachna Street, Vinnytsia, Ukraine, 21008 e-mail: alenagnatyuk1@gmail.com). 